\title{
Nosy Be (Madagascar) and the neighbouring islands versus tourism development
}

\begin{abstract}
Madagascar is one of the trendiest holiday destinations. One of two key destinations is Nosy Be and surrounding smaller islands. It can be considered a local tourist hub. This work aims to illustrate the variability of the region's tourism evolution in reference to Butler's concept, and to specify circumstances characteristic of tropical islands, especially in less developed countries. Typology of islands has been performed according to level of tourism development; moreover, the brief evolution of post-1960s tourism development was assessed. The archipelago's evolutionary stages of tourism development are significantly diversified, evolution has been non-linear and not always unidirectional. It is difficult to observe all stages of the cycle. The stage tends to be hard to determine, evolutionary pace tends to vary, and some stages are absent. Regional under-development and external factors may cause a regression in development. No stage changes were observed on most islands where enclave tourism developed.
\end{abstract}

Keywords

Nosy $\mathrm{Be} \cdot$ tropical island $\cdot$ tourist area cycle of evolution $\cdot$ tourism development $\cdot$ Madagascar

(c) University of Warsaw - Faculty of Geography and Regional Studies

Introduction

Today, Madagascar is becoming increasingly popular as a tourist destination, although tourist traffic is relatively light (approx. 300,000 in 2016, like on much lesser Seychelles; for small Mauritius and Maldives the value exceeds 1,200,000!) and the tourist base is modest but growing. One of the two most important routes chosen by tourists involves Nosy Be, and the surrounding smaller islands in the Mozambique Channel. As tourism radiates out to the neighbouring islands, Nosy Be can be regarded as a local hub for tourism development.

Studies in tourism development are a significant research problem for the geography of tourism, and tropical islands (small ones in particular) have attracted a lot of studies in recent decades. They have been studied in various contexts and at various historical points, particularly assessing the relationships between the development of tourism and the economies of islands and archipelagos (Wellas, Cauet 1997; Connell 1988; David 2003; Podhorodecka 2017, 2018; Singaravelou 1984; Wilkinson 1989). Theoretical models such as MIRAB (Bertram, Watters 1985) have been developed. Stages of tourism development have been identified by, inter alia, R. W. Butler (1980, ed. 2006), E. Gormsen (1982, 1997), J.-M. Miossec (1977), and M. Oppermann (1993). Tourism development in tropical countries, including enclave tourism, has been studied by S. Britton (1982), T. G. Freitag (1994), O.Dehoorne \& P.Saffache (2008), Jędrusik (2004) and J.-Ch. Gay (2001). Different aspects of tourism were analysed by J.O. Bærenholdt, M. Haldrup \& J. Urry (2004), M. Haldrup \& J. Larsen (2010), J. Larsen \& J.Urry (2011), or J.F. Hoareau (ed.2016). An interesting theory of the evolution of tourism space was created by S. Liszewski (1995).

\author{
Maciej Henryk Jedrusik \\ Faculty of Geography and Regional Studies, \\ University of Warsaw, Poland \\ e-mail: m.jedrusik@uw.edu.pl \\ Received: 29 October 2018 \\ Accepted: 29 December 2018
}

Although each of these concepts can be critically applied to the reality of tourism on Nosy Be, this paper aims to present the diversity of tourism evolution in this area in reference solely to the concept by R. W. Butler (1980) and to identify specific phenomena he did not notice, which are characteristic of tropical islands, and especially those in poor countries. To this end, a typology of the studied islands based on the previous (Jędrusik 2011b) methodology was presented, considering tourism development and exploitation, and the evolution of tourism development since 1960 on islands of each type was assessed. The indicated types were hereby confronted with the Butler model. The article is the result of two field observations carried out in 2007 and 2015.

\section{Madagascar as a tourist destination}

Madagascar attracts tourists for the singular nature of its environment (including its high rate of endemic species). It has become a destination for nature-based tourism. However, various barriers (e.g. political instability which handicaps foreign investments, the difficulties to set up the necessary infrastructure, significant health threats, insecurity of visitors who are attacked in a few areas, especially in the South where ransacking rebels are rampant) and the lack of a solid development plan of tourism strategy, mean that tourist traffic has remained small. Tourist numbers fluctuate significantly, especially at times of political turbulence (Fig. 1). Over all, it is growing, but remains modest considering the size of the country and its population. This is partly the result of poor tourism development. According to official data for 2005, Madagascar had only 937 hotels of various 


\section{Number of tourists in Madagascar (000s)}

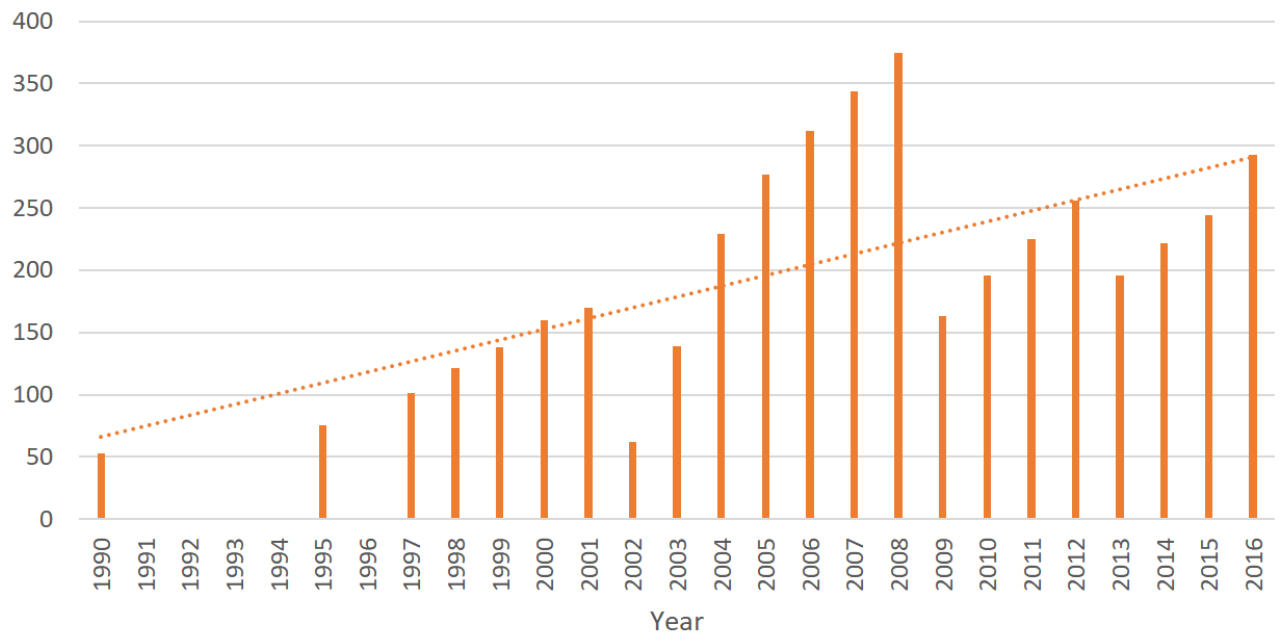

Figure 1. Number of foreign tourists' arrivals on Madagascar in 1990-2016 based on: The World Bank https://data.worldbank.org/ indicator/ST.INT.ARVL?locations=MG

Table 1. Changes in the accommodation base on Madagascar in the 21 st century

\begin{tabular}{|c|c|c|c|c|c|c|}
\hline & $\mathbf{2 0 0 5}^{\mathbf{a}}$ & $\mathbf{2 0 1 1}$ & $\mathbf{2 0 1 2}$ & $\mathbf{2 0 1 3}$ & $\mathbf{2 0 1 4}$ & $\mathbf{2 0 1 5}$ \\
\hline $\begin{array}{c}\text { Number of } \\
\text { accommodation } \\
\text { facilities }\end{array}$ & n.a. & 2,712 & 3,290 & 3,607 & 3,757 & 3,981 \\
\hline Of which, hotels & 937 & 1,693 & 2,010 & 2,251 & 2,377 & 2,558 \\
\hline Number of rooms & 10,879 & 19,112 & 20,520 & 22,263 & 23,382 & 24,046 \\
\hline Number of beds & n.a. & 30,388 & 32,627 & 35,398 & 37,154 & n.a. \\
\hline
\end{tabular}

Source: World Tourism Organization (2016), Compendium of Tourism Statistics dataset [Electronic], UNWTO, Madrid, data updated on $24 / 11 / 2016$.

${ }^{a}$ Annuaire ... 2007, p.30-31

classes and sizes, and 713 organised campsites, and its total hotel capacity was 10,879 rooms (Annuaire ... 2007, pp. 30-31). Most of the hotels had only a few rooms, no air conditioning, and limited access to electricity. Only 94 hotels had internet access and so were "visible" on the web, including on tourism websites. Despite these shortcomings, between 2002 and 2005, the hotel base increased by $25 \%$, and its use increased from $22 \%$ to $55 \%$. Later data indicate that the number of accommodation facilities has also grown since 2011 (Table 1), although it is still far from the saturation level known to other islands of the Indian Ocean Seychelles, the Mascarenes, and the Maldives.

More than half of the tourists visiting Madagascar are choosing the Antananarivo-Tulear route that runs along the Central Plateau. They prefer nature-based tourism and are attracted by the endemic flora and fauna and particular features of Malagasy culture. The same increasing trend is observed for leisure tourism, which is directed at small Malagasy islands on the Mozambique Channel. So, the second tourist stream in terms of importance and scale is created.

The touristic value of Nosy Be

Nosy Be is the central point of an archipelago of over 200 smaller islands whose areas do not exceed a few dozen square kilometres (Fig. 2) and, as "insular" it distinguishes very much from the "continental" Madagascar (Jędrusik 2011c).
The largest of the mentioned islands, Nosy Be $\left(321 \mathrm{~km}^{2}\right)$, was already attracting its first tourists by the 1960s. It is distinguished from the rest of the country by its economy, history and culture. This culture is more strongly connected with the sea. The small area of the island and its tourist offers are essential too. Declared a French protectorate on 5 March 1841, it remained an independent French territory until 30 March 1957, and then, united with Madagascar, the two gained independence in 1960.

The island is accessible to tourists by water, with fast boats from Ankify (about 1 hour) and by air, with connections mainly with Antananarivo, as well as with Reunion and Mayotte. Periodically, the airport on the island has received flights from Rome, Milan and Paris, as well as from Johannesburg and Beira (Mozambique). This is how most tourists has chosen to travel.

They are looking for a different attraction: natural - over 300 days of sunshine a year, clean and clear waters, numerous sandy beaches attract sunbathers and divers or the landscape which has noticeable traces of extinct volcanoes, but also anthropogenic - maybe because the island's reputation as a sex tourism destination. French, German, South African and Italian tourists predominate. The majority is male.

A dozen or so volcanic cones, including the peaks of Lokobe (about $450 \mathrm{~m}$ ) and Mont Passot $(329 \mathrm{~m}$ ), the abundant lush vegetation, several waterfalls and a dozen crater lakes, all add diversity to the landscape of the island's interior, as do the ylang- 


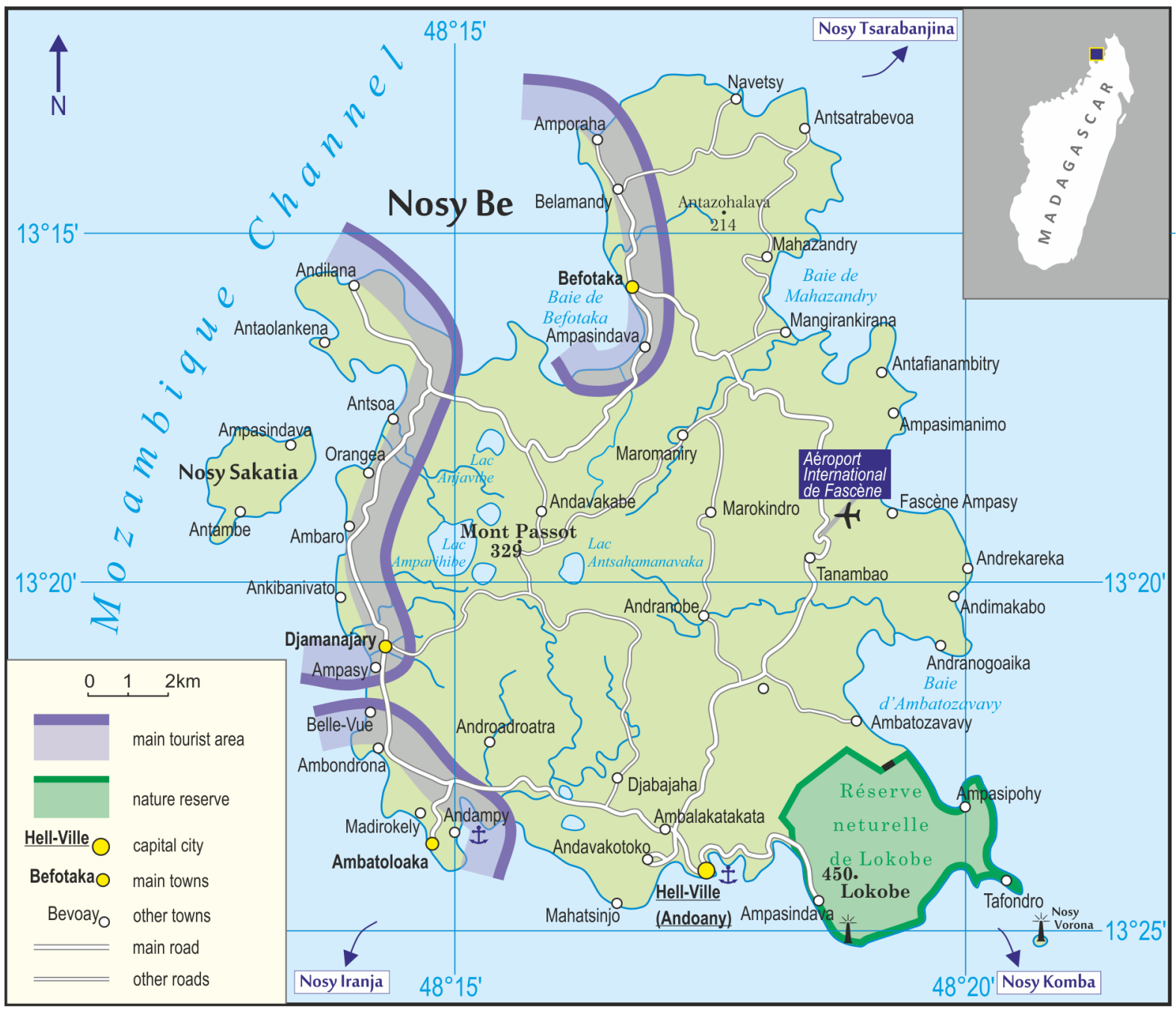

Figure 2. Features of tourist areas on Nosy Be. (Authors: M. Jędrusik, I. Gołębiowska).

ylang plantations (which account for half of the world's production of the essential oil) and sugar cane plantations. Ylang-ylang plantations were established in the 1920s. They gave Nosy Be its nickname as "the perfume island". You can visit the significant distillery of ylang-ylang oil near Andoany, and the neighbouring Lemuria Land (a kind of safari park, with numerous species of lemurs). In the south-eastern part of Nosy Be is located the Lokobe National Park (where the numerous lemurs and boa snakes live) the last fragment of the original forest which grew on the majority of the island in the 19th century, cut for the sugar cane and ylangylang plantations, for its valuable wood, and above disappearing as a result of the slash-and-burn tactics of the growing population (5,000 in 1842, over 33,000 in 1918) (Petit 2006, pp. 197-199). The forest probably only survived through the establishment of the reserve in Lokobe in 1929. Now, trekking excursions through it, and through the centre and east of the island, as well as the quad bike trips on Mont Passot, are significant attractions in terms of exploring the interior of Nosy Be.

Nosy Be's most important neighbours are: to the east, Nosy Komba, Nosy Tanikely and Nosy Faly; to the west Nosy Sakatia; and a certain distance to the south-west, Nosy Iranja. Near Nosy Be there is also the Mitsio archipelago, with the relatively larger Nosy Mitsio, Nosy Lava and Nosy
Tsarabanjina. Further north, near the city of Antsiranana, the largest islands are Nosy Valiha and Nosy Hara, which form an archipelago of 12 islands surrounded by coral reefs. To the southwest there is the Radama archipelago with the largest island of Nosy Berafia, as well as Nosy Ovy, Nosy Antanimora, Nosy Kalakajoro, Nosy Valiha and a few minor ones (Madagasikara et ... 2006). Many of these islands have become destinations for daytrips from Nosy Be. On some, hotels have been built (Nosy Iranja, Nosy Komba, Nosy Sakatia, Nosy Tsarabanjina).

\section{The evolution of tourism development} Initiation (1960-2000)

Connections to the sea have contributed to the development of the tourism infrastructure. Nosy Be's tourism initiation period (involvement; exploration) is considered to be 1960; that is, the year in which Madagascar gained independence. This does not mean that tourists had not been there before, but even a basic tourism infrastructure was absent. The existence of an airport (one of 48 terrains d'aviation on the island) on Nosy Be is confirmed by Ch. Robequain (1958, p. 299), although he does not mention there being tourists on Nosy Be. Similarly, there is information about Nosy Be in the works of R. Battistini $(1967,1979)$. The Atlas de Madagascar (1971, p. 51) mentions Fascene airport 
as a category-two (of four) facility that could receive DC4 aircraft, was equipped with a radio beacon, had radio communication and was equipped to receive night flights. Towards the end of the 1960s it was a domestic airport, and the main stream of passengers (about 3,000 a year) headed to Antsohihy and onwards to Mahajanga. Slightly fewer people travelled by plane to Antsiranana (fewer than 3,000) and Ambilobe. There is also a mention of the island's significant touristic value. The tourist guide "Madagascar aujourd'hui" of the late 1970s mentions tourism dating back to the nineteenth century, and identifies its protagonists as, among others, seamen from a Russian ship stationed there in the years 1904-1905 (Andriamirado, 1978). However, this interpretation is dubious. Nevertheless, in terms of the 1970s, the guide also mentions hotels existing in Hellville (Andoany), in Andilana in the north west ("the luxury, but ugly, Holiday Inn Andilana Beach opened in 1972") and in Ampahora in the north. There is also information that other places on the island which were considered hard to reach did not attract the attention of investors (ibid., p. 172). The accommodation proposed to tourists in the publication is modest, comprising four hotels, totalling 182 rooms of various standards. It also mentioned the reopening of a hotel (the Cocotier) in Djamandjary in 1978. The hoteliers organised boat trips to neighbouring islands (the farthest being Nosy Mitsio), which was then undeveloped for tourism.

Nosy Be (Fig. 3) became a more major tourist destination in the 1970s, although the number of tourists remained small (cautious estimates are of several thousand people per year). From the beginning, the island was an especially popular destination for the French, and later became a favourite destination of Italians, as well as Germans and South Africans. More significant accommodation facilities began to appear towards the end of the 20th century in response to the modest growth in incoming traffic to Madagascar. The tourist movement increased slightly after 1984, when the Malagasy authorities of the time decided on a cautious opening up of the country and support for tourism, and much more after 2002, alongside significant political changes. It grew until the next political shakeups towards the end of the first decade of the 21st century. In response to the growing tourist demand and the liberalisation of business and political life, new hotels were constructed to higher standards, including luxury facilities both on Nosy Be and on its neighbouring islands. However, as J.-L. Guébourg writes: "the ephemeral nature of tourist facilities hinders any study on the phenomenon of the tourist explosion" (Guébourg 1999, p. 315). The author judged that in the mid-1990s luxury hotels which had opened in the 1970s were in crisis. Andilana Beach had become severely degraded and after several attempts to reinvigorate it the oldest hotel, the Palm Beach, was closed in 1990. It listed the hotel base as consisting of only 5 hotels of various standards (with a total of only slightly over 100 rooms or bungalows) which it recognised as being fit for tourists (ibid. p. 316). He also emphasised that the road network was insufficiently developed and of poor quality (ibid. p. 322).

\section{The first decade of the 21st century}

In 2006, official statistics indicated that there were 32 hotels and 38 "hotels-restaurants" on the island (Annuaire... 2007 pp. 67-72), which represented almost $8 \%$ of Madagascar's entire registered hotel base. Relative to Nosy Be's modest proportion of Madagascar's total area $(0.05 \%)$ and population $(0.2 \%)$, this was an indication of the island's importance as a national tourist hub. The quality of accommodation was varied, and the best hotels were concentrated along the most attractive coasts of the west and north-west.

The tourist development of smaller neighbouring islands has only progressed since the beginning of the 21 st century.

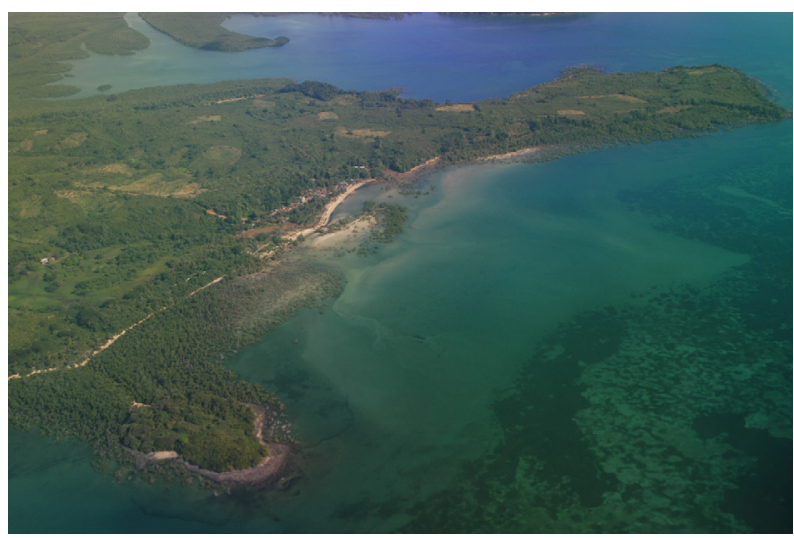

Figure 3. The island of Nosy Be (Photo: M. Jędrusik)

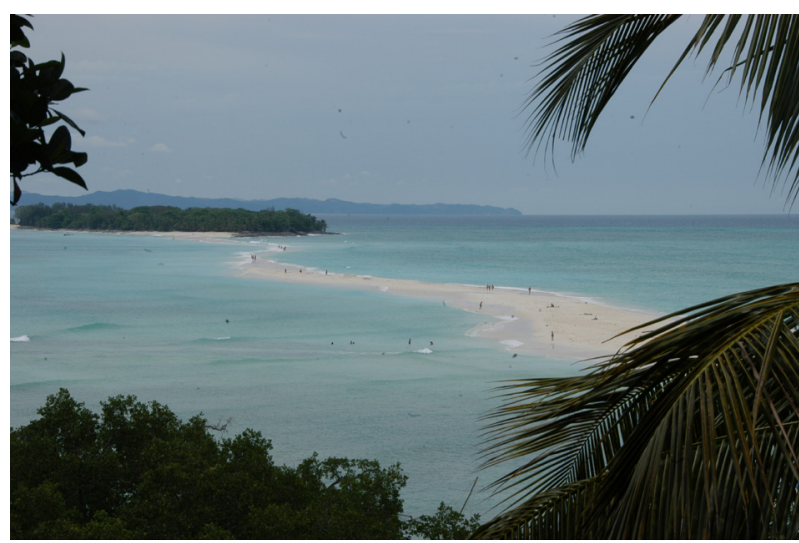

Figure 4. Nosy Iranja (Photo: M. Jędrusik).

They began to attract investors (more in: Jedrusik 2011b) seeking revenue from the creation of luxury hotels following the islandhotel model known from the Maldives or Seychelles (Gay 2001). This was premised on the modest size of the islands, the ease of building the infrastructure, the lack of local population and outstanding natural value.

In 2006, on the neighbouring islands, there was a hotel base on Nosy Komba $\left(27.9 \mathrm{~km}^{2}\right)$, with the most important hotel being the Tsara Komba Lodge (8 bungalows), with additional accommodation offered in village guest houses. On Nosy Sakatia (about $3 \mathrm{~km}^{2}$ ) there was a 3-star hotel (Sakatia Lodge) which was built in 2004 and opened in 2006, and a diving centre with 11 bungalows. On the smaller of the Nosy Iranja islands measuring $1 \mathrm{~km}^{2}$ and connected by a shoal (Iranja Kely), the luxurious Nosy Iranja Beach (Fig.4). Resort was created, with 29 bungalows. In the Mitsio archipelago, on Nosy Tsarabanjina, about $37 \mathrm{~km}$ off the shores of Nosy Bé, a luxury hotel operated (Constance Lodge Tsarabanjina). The largest of the islands of the archipelago, Nosy Mitsio $\left(29.7 \mathrm{~km}^{2}\right)$ was visited by less wealthy tourists (Fig.5). There was a hotel with bungalows on stilts, and it was also possible to stay in the village (Le petit futé ... 2006, p. 496; Petit futé Madagascar 2014). However, it was not possible to book accommodation online. Among the islands of the southern group, Nosy Saba $\left(1.3 \mathrm{~km}^{2}\right)$ stood out in terms of tourism development. The whole island is today the premises of a luxury hotel (Nosy Saba Island Resort) with a private runway.

Other islands in the immediate vicinity of Nosy Be have no tourist base and are often uninhabited. Tourists keenly frequented 
Table 2. Number of accommodation facilities on Nosy Be according to tourism websites

\begin{tabular}{|c|c|c|c|c|c|c|c|c|}
\hline & $\mathbf{2 0 0 6} \mathbf{1}^{\mathbf{1}}$ & $\begin{array}{c}\text { TripAd- } \\
\text { visor }\end{array}$ & $\begin{array}{c}\text { Resorts } \\
\text { Guides }\end{array}$ & $\begin{array}{c}\text { Booking. } \\
\text { com }\end{array}$ & $\begin{array}{c}\text { Lonely } \\
\text { Planet }\end{array}$ & Travelmadagascar.org & $\begin{array}{c}\text { Google } \\
\text { Maps }^{2}\end{array}$ & $\begin{array}{c}\text { Average } \\
\mathbf{2 0 1 8}\end{array}$ \\
\hline Hotels & 32 & 31 & - & 20 & - & - & & \\
\hline $\begin{array}{c}\text { Guest houses } \\
\text { and similar }\end{array}$ & 38 & 48 & - & 15 & - & - & & \\
\hline Other facilities & - & 32 & - & 54 & - & - & & \\
\hline Total & $\mathbf{7 0}$ & 111 & $\mathbf{6 3}$ & $\mathbf{8 9}$ & $\mathbf{1 0 0}$ & $\mathbf{4 1}$ & $\mathbf{7 6}$ & $\mathbf{8 0}$ \\
\hline
\end{tabular}

Source: ${ }^{1}$ Annuaire ... 2007, p.30-31

${ }^{2}$ https://www.google.pl/maps/@-13.3094475,48.2375171,25979m/data=!3m1!1e3 (1.02.2018) - image date 032016 and 072015

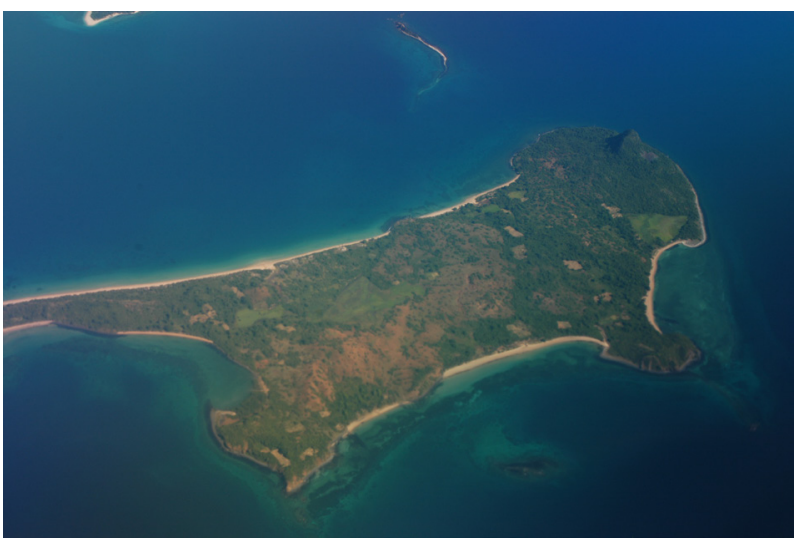

Figure 5. Nosy Mitsio (Photo: M. Jędrusik)

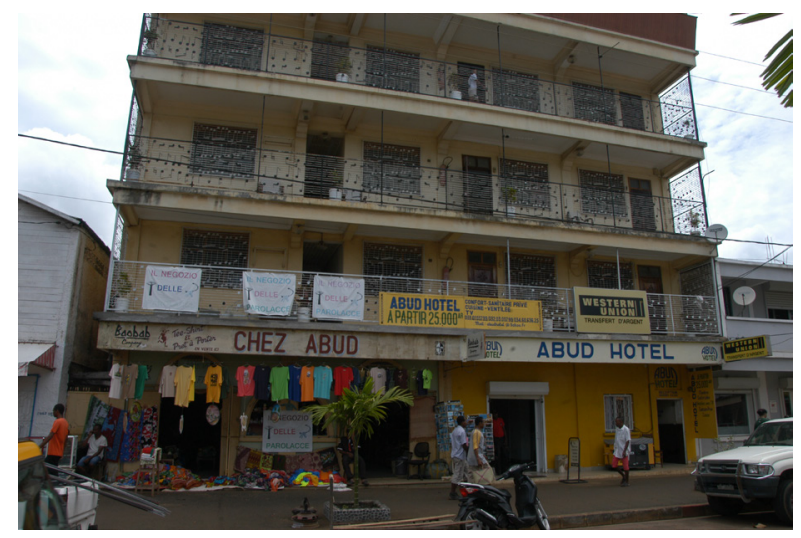

Figure 6. Abud Hotel in Andoany (Photo: M. Jędrusik)

Nosy Tanikely (about $0.2 \mathrm{~km}^{2}$ ), with its white beaches and extensive coral reef and lemur populations, as well as Nosy Valiha and the Hara archipelago.

The end of the first decade of the 21st century brought political unrest and economic collapse in Madagascar, resulting in a rapid reduction in tourism. The number of arrivals on Nosy Be decreased proportionally, although the island avoided the worst of the riots. It had the advantage of an international airport (Fascene) serving, among others, several direct flights to foreign countries, including charter flights (Pitcher, Wright 2004, p. 154). Only in 2011 did Madagascar's tourist numbers approach the 225,000 of 2004. Since 2012, the number of accommodation facilities in Madagascar has increased (Table 1). While the tourist traffic on Nosy Be grew proportionally to that of Madagascar, the accommodation base grew more slowly.

The opening of several new hotels in 2010 and 2011 was not accompanied by the development of infrastructure - the island lacked waterworks and good roads. The supply of beds far exceeded demand (Wikipedia Nosy Be 2018).

The middle of the second decade of the 21 st century

In 2016, Fascene Airport serviced 47,000 passengers, of which two-thirds (approximately 37,000) were tourists (Bouygues Construction Press Release). Due to the steady increase in passenger traffic, in May 2017 a decision was taken to ensure the full refurbishment of the runway and of the existing terminal, and the technical and environmental compliance of facilities.

In the 10 years up to 2018, the number of hotels on Nosy Be increased only slightly. Shortcomings in statistics and official data makes it difficult to determine the exact number of accommodation facilities. In February 2018, the Tripadvisor website's accommodation map indicated 31 hotels, 48 "B\&B and Inns", and 32 other "Vacation Rentals" ( TripAdvisor New Zealand 2018 Nosy Be Hotels-g479206). Of these other "Vacation Rentals" only 13 included a price, which might indicate the limited availability of facilities. The same was true of 16 of the "B\&B and Inns" and 11 of the hotels.

Meanwhile, the Resorts Guides website, listed 63 hotels and guesthouses on Nosy Be in the same period (Resort Guides Search Resorts at Nosy Be 2018). The website booking.com offered 20 hotels, 15 guesthouses and 54 other facilities. (Booking.com Search result). Meanwhile, travelmadagascar.org offered 41 facilities (broken down by type) in different parts of the island (Travel Madagascar Madagascar Travel Guide), while Lonely Planet offered 100 (Lonely Planet Search Lonely Planet and Beyond).

The distribution of accommodation facilities in the period 2006-2018 changed slightly. This makes sense considering the location of natural assets. Over $80 \%$ of the entire base was concentrated on the best beaches in the west and north of the island, while the south (including the island's capital of Andoany) hosted only $9 \%$, and the east (mainly around Lokobe National Park) only $7 \%$. In some places, there have been significant functional and physiognomic changes, which have degraded the touristic space. Ambatoloaka (in the south-west), has gone from being a fishing village to a chaotically developed tourist service centre (with equipment rentals, tourist agencies, bars, a casino, and numerous [18] medium-class hotels).

Despite this, tourist service quality has been assessed as low (Fig. 6-9). As the Lonely Planet guide pointed out: "organised activities in Nosy Be are still in relative infancy. To really get off the beaten path charter a boat with a local fisherman." (Andrew et al. 2008, p. 162).

The vacation rental base on the neighbouring islands has also not seen the expected changes and has even been 


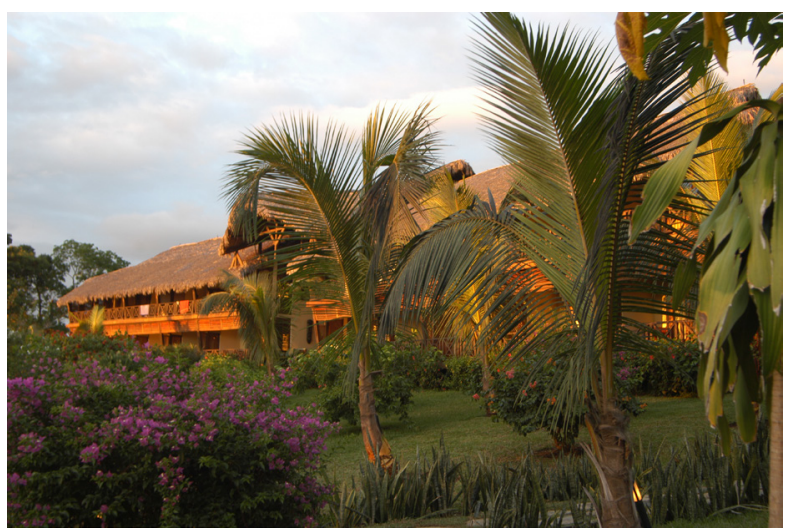

Figure 7. 3-stars Vanilla Hotel in Ambaro (western Nosy Be) (Photo: M. Jędrusik)

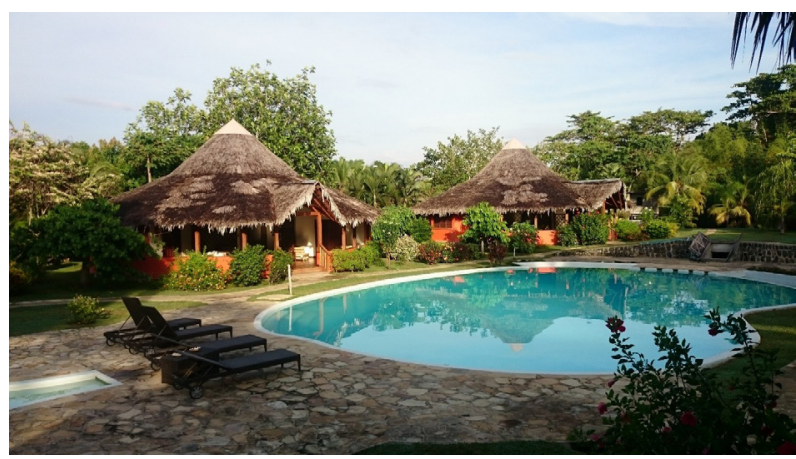

Figure 8. Loharano Hotel near Ambaro (Photo: M. Jędrusik)

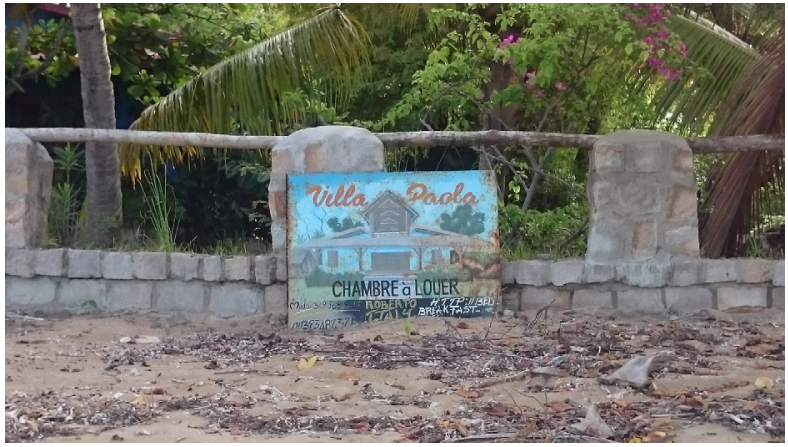

Figure 9. Example of a tourist advertisement on Nosy Be (2015) (Photo: M. Jędrusik)

impoverished. In February 2018, tourist websites did not feature Nosy Iranja - not even the "best populated" website, Lonely Planet. Several new facilities have been built on Nosy Komba and Nosy Sakatia - in most cases they are single, private houses being rented out to tourists. The largest number of such facilities is given by Lonely Planet, with 13 on Nosy Komba and 4 on Nosy Sakatia. In both cases, this is only supplementary to the offer of the still-operating, large, well-rated hotels which were built at the beginning of the century. New hotels have not appeared on any other island. On Nosy $\mathrm{Be}$ and a few neighbouring islands, it is also possible to find accommodation among the locals.
The island's infrastructure has not improved in recent years. Air connections have deteriorated, in terms of both frequency and quality (measured in, among others, punctuality). The phenomenon has been observable since 2014. Numerous flights were cancelled or delayed (even by over a day). There were also flights departing well before the scheduled time (observations from November 2015), which hindered the planning of journeys and required local tourist agents to be extremely adaptable. Since February 2016, the regularity of flights has been restored (on the Madagascar-wide scale) (93\% of flights were within 30 minutes of schedule) (Wikipedia Air Madagascar). In January 2018, Fascene airport received 20 regular flights a week, the largest single destination (8 flights) being Antananarivo. The remaining flights connected the island with Dzaoudzi (Mayotte) - 4 flights, SaintDenis (Reunion) -3 , Antsiranana -3 , and one each with Beira (Mozambique) and Zanzibar. The number of incoming flights did not exceed 5 per day (for example 13.02.2018: 2 flights to Mayotte, 1 each to Antananarivo, Antsiranana and Reunion) (Flight Radar 24 Nosy Be Fascene Airport). Between 26.01 and 1.02.2018, the website airportia.com showed 15 arrivals: 6 from Antananarivo, 3 from Reunion, 3 from Mayotte, and 1 each from Zanzibar and Johannesburg (Airportia The Airport Guide Madagascar Airports). This may additionally show the significant variation in frequency of connections over time. Furthermore, the short runway $(2,190 \mathrm{~m})$ does not allow large aircraft to land. In such conditions, tourist traffic is limited by an infrastructure barrier.

In this decade, tourism traffic has been influenced not only by national political turmoil, but also by incidents of a social nature. In October 2013, a crowd lynched two French tourists on the beach. This had serious repercussions in France, reducing the popularity of Nosy $\mathrm{Be}$ as a travel destination ('Révélations sur l'effroyable lynchage de NosyBe'). Decreasing tourist service quality and extortion attempts account for the decline in popularity of hotels on Nosy Iranja and their disappearance from tourist websites. The number of decidedly critical reviews on Tripadvisor. com increased significantly after 2012. There have been entries calling for a boycott of the place (TripAdvisor New Zealand 2018, Nosy Iranja Lodge r122939144).

There were also allegations concerning the degradation of the natural environment, corruption, exorbitant prices, and the poor technical condition of the facility with an entry from 11.2.2012 reading:

This island has enormous potential: the sea is crystal clear, the white beach where there are lots of eggs of sea turtles, which can be admired at the time of deposition of the birth. We were lucky enough to attend both events. INCREDIBLE! A unique experience that I will always remain in my heart. But after two nights we escaped! The Resort is decadent and should undergo many systematic restructurings. By spending almost 500 euro per day is right to offer a structure and an adequate service. The correct cost for such a place should not exceed 50/60 euro a day. ( TripAdvisor New Zealand 2018, Nosy Iranja Lodge r158511267)

Island types in the archipelago, by tourism development

Based on the characteristics of Nosy Be and neighbouring islands, five types of tourist use (Fig. 10) can be distinguished [see more in: Jędrusik 2011a, 2011b].

Type I - tourist enclaves, small islands $\left(1-2 \mathrm{~km}^{2}\right)$ originally uninhabited, with luxury hotels. Limited access for locals. Package tours predominate (Nosy Iranja Kely, Nosy Saba, Nosy Tsarabanjina).

Type II - larger, inhabited islands, mixed tourism. Diverse standards of hotel, frequently for one-day trips. Access is not limited (Nosy Be, Nosy Komba, Nosy Sakatia, Nosy Iranja Be).

Type III - relatively large, inhabited islands, poor accommodation base, diving spots (Nosy Mitsio and Nosy Faly). 


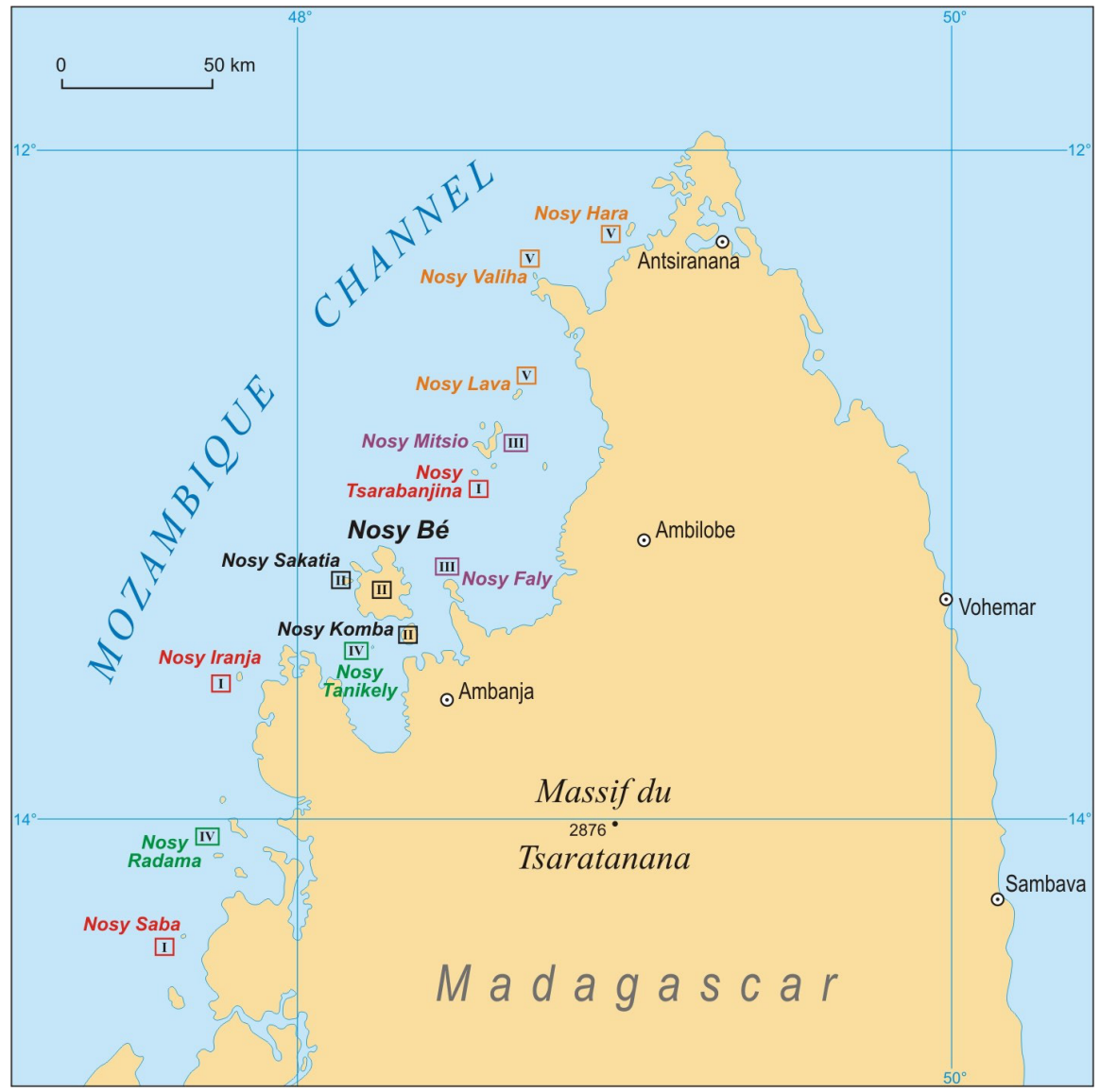

Figure 10. Small islands and the types of their tourist use. Explanation of the types in the text (After: Jedrusik 2011 b).

Type IV - small, uninhabited islands, diving spots (Nosy Tanikely, Radama archipelago).

Type V - numerous small, uninhabited, undeveloped islands; a reservoir for tourism development (Nosy Lava, Nosy Hara, Nosy Valiha).

Tourism on Nosy Be vs Butler's concept of a tourist area's cycle of evolution

R. W. Butler's (1980) concept of the cycle of tourist area evolution has at least five stages: from exploration to stagnation and its consequences. This hypothetical model was developed almost 40 years ago. Over the past four decades, huge global changes in tourism have been observed all over the world. What's more, in justifying and explaining the features of evolutionary stages, R. W. Butler used the examples of areas of various sizes, from individual tourist destinations to countries and even significant portions of continents. Such a synthetic view of the phenomenon is of value, but it obscures nuances. Where would this concept place Nosy Be?

The island is a compact, unified tourist area, but has been subject to change since tourism "initiation". The lack of accurate statistics on the number of tourists of course makes precise analysis difficult. For simplicity, it may therefore be assumed that the stream of tourists arriving on Nosy Be and its changes correspond to tourist traffic into Madagascar.

R. W. Butler distinguishes and describes the following stages: 1. exploration [E] - "visitors will come to an area in small numbers initially, restricted by lack of access, facilities and local knowledge" (p.6);
2. involvement [I] - "some local residents (...) begin to provide facilities primarily or even exclusively for visitors" (p.7);

3. development - "reflects a well-defined tourist market area (...) [D1]. Some locally provided facilities will have disappeared being superseded by (...) external organizations, particularly for visitor accommodation. [D2] (...) Changes in the physical appearance of the area will be noticeable. [D3] (...) The number of tourists at peak periods will probably equal or exceed the permanent local population" [D4]. (p.8);

4. consolidation - "total visitor numbers exceed the number of permanent residents [C1] (...). A major part of the area's economy will be tied to tourism. [C2] (...) The resort cities will have well-defined recreational business districts" [C3] (...) (p.8)

5. stagnation - "Capacity levels for many variables will have been reached or exceeded, with attendant environmental, social, and economic problems. The area will have a well-established image, but it will no longer be in fashion [S1] (...). Surplus bed capacity will be available [S2] (...) The resort image becomes divorced from its geographic environment" [S3] (p.8);

The author also describes the features of a decline and a rejuvenation stage, but these are inadequate in the context of Nosy $\mathrm{Be}$ and the neighbouring archipelago. Nosy Iranja Kely is the only example of the next stage of decline in the study area. However, there is no objective and sufficient data on which to draw deeper conclusions about this area. 
MISCELLANEA GEOGRAPHICA - REGIONAL STUDIES ON DEVELOPMENT

Vol. 23 • No. 1 - 2019 • pp. 23-32 • ISSN: 2084-6118 • DOI: 10.2478/mgrsd-2019-0001

Table 3 Stages of tourist area cycle of evolution on Nosy Be and neighbouring islands

\begin{tabular}{|c|c|c|c|c|c|}
\hline Stage & & Nosy Be & TYPE I & TYPE II & TYPE III \\
\hline exploration & $\mathbf{E}$ & $+(1960-1972)$ & 0 & $+(1990-2002)$ & $+(1990-2002)$ \\
\hline involvement & I & $+(1973-1990)$ & 0 & $+(2002-2006 ?)$ & + (to 2018?) \\
\hline \multirow[t]{4}{*}{ development } & D1 & + & + & - & 0 \\
\hline & D2 & $-/+$ & - & - & 0 \\
\hline & D3 & + & - & - & 0 \\
\hline & D4 & - & 0 & - & 0 \\
\hline \multirow[t]{3}{*}{ consolidation } & C1 & - & + & - & 0 \\
\hline & $\mathrm{C2}$ & - & + & + & 0 \\
\hline & C3 & $-1+$ & + & - & 0 \\
\hline \multirow[t]{3}{*}{ stagnation } & $\mathrm{S1}$ & + & - & - & 0 \\
\hline & S2 & + & - & - & 0 \\
\hline & S3 & - & - & - & 0 \\
\hline
\end{tabular}

+ present

- not present

0 not applicable

Which of the above traits have been, and are, present on Nosy Be and neighbouring islands?

a) Exploration - for Nosy Be this stage can be dated as lasting from the Independence of Madagascar (or earlier) to the early 1970s. The neighbouring islands (type II and III) only entered this stage towards the end of the 20th century.

b) Involvement - it is difficult to determine the beginning of this period for Nosy Be; perhaps in the 1970s; liberalisation of the tourism policy after 1984 was conducive to it. The neighbouring islands entered this period somewhat later, stimulated by growing interest from visitors to Nosy Be. The type-I islands avoided the first two stages, including involvement, because tourism was created there "from scratch". What is more, their distance from Nosy Be (4-6 hours by boat, private airport on Nosy Saba) indicate their tourist development having low dependence on Nosy Be. The involvement stage relates to type-II islands, where it may have ended in the first decade of the 21 st century and continues to this day on the type-III islands.

c) Development - the traits indicated by R. W. Butler are visible on Nosy Be: the tourist market is defined; there are cases of local businesses being replaced by chains, although there is still room for both forms to co-exist; some areas (Ambatoloaka) have changed their physiognomy. On the type-I islands the tourist market area is precisely defined, while on the type-II islands none of the characteristics of "development" is noticeable.

d) Consolidation - consolidation is more pronounced on the type-I islands, which have in fact been exclusively in this stage from the very beginning - which seems to be a characteristic feature of enclave tourism. "Strong but indirect" seems to best describe the link between the economies of type-II islands and tourism. However, it is difficult to find characteristics of consolidation on Nosy Be.

e) Stagnation - this stage, meanwhile, can be seen only on Nosy Be, in that tourism supply (especially accommodation) far exceeds demand; travel trends are variable and depend on incidents, political situations and social moods. These phenomena are not observable on the other islands.
The observations about Nosy Be and its neighbouring islands gathered together here, in combination with R. W. Butler's traits characterising the various stages of evolution, allow the following general (of course) statement to be made (Table 3).

\section{Conclusion}

They allow the following conclusions to be drawn

a) not all the stages assumed by R. W. Butler can be distinguished in the study area;

b) according to the assumptions of R. W. Butler's concept, the archipelago is not a uniform area, and the tourist evolution proceeds in a different order on the main island (Nosy Be) than on the neighbouring tourist islands;

c) type-l islands are "more mature" and have thus far remained in the consolidation stage since the beginning; meanwhile, no consolidation stage is noticeable on Nosy Be;

d) type-II islands are in a difficult-to-define stage - in some respects they are close to consolidation (apart from the development features identified above), most of them resemble the involvement stage;

e) type-III islands have basically not gone beyond the involvement stage;

f) generally, many features of the Nosy Be tourist area indicate poor development, yet the island seems to be reaching the stagnation stage.

So, in the tourist development of the archipelago, it is difficult to notice all the stages of the cycle proposed by R. W. Butler. The evolution of this tourist area has skipped certain stages. The momentum of the evolutionary cycle may be difficult to determine. The pace of evolution varies, and is not even one-way, because the underdevelopment of the area and external circumstances may cause a regression in development (which was particularly visible in the years 2008-2012). However, the financial success of island-hotels may lead to further investments on other small, uninhabited islands of the area. The capital interest in the surrounding area is visible on websites. This and the expansion of Fascene Airport is creating an opportunity for Nosy Be to break its stagnation. This will require significant investments, which 
may be beyond the budget of Madagascar, one of the world's poorest countries. This leaves foreign capital, and this may lead to tourism neo-colonialism.

Investments in improving infrastructure quality aim to increase tourist traffic. It is hard not to notice that many tropical islands are competing for the same type of tourists, including in this region (the Mascarenes, Seychelles and Maldives). The attraction of
Nosy Be to date has been its relative underdevelopment, lending it value as "virgin territory". Investments and growth in tourist traffic will allow the area to enter the next stage of the evolution cycle (rejuvenation), but this will eradicate this value. So, is this a dream worth dreaming? Will it really be a rejuvenation?

Translated by Tim Brombley (Wordlink)

\section{References}

Airportia. The Airport Guide 2018, Madagascar Airports. Available from: <https://www.airportia.com/madagascar>. [1 February 2018].

Andrew, D et al. 2008, Madagascar\&Comoros, Lonely Planet Publications Pty Ltd, Footscray.

Andriamirado, S 1978, Madagascar aujourd'hui, Editions Jeune Afrique, Paris.

Annuaire officiel du tourisme 2006 2007, no ed, Antananarivo.

Atlas de Madagascar 1971, L'Association des Géographes de Madagascar, Tananarive.

Bærenholdt, J, Haldrup, M \& Urry, J 2004, Performing tourist places, Routledge, London.

Battistini, R 1967, L'Afrique Australe et Madagascar, Presses Universitaires de France, Paris.

Battistini, R 1979, L'Afrique Australe et Madagascar (édition 2e), Presses Universitaires de France, Paris.

Bertram, IG \& Watters, F 1985, 'The MIRAB economy in South Pacific microstates', Pacific Viewpoint, vol. 26(3), pp. 497519.

Booking.com 2018, Search results. Nosy Be Island. Available from: $\quad<$ https://www.booking.com/searchresults. pl.html?aid=383263\&label=nosy-be-island $>$. [1 February 2018].

Bouygues Construction 2018, Press Release. Available from: <http://www.bouygues-construction.com/en/press/release/ ravinala-airports-concession-company-antananarivoand-nosy-be-madagascar-formed-groupe-adp-bouyguesbatiment-international-colas-and-meridiam-africa>. February 2018].

Britton, SG, 1982, 'The political economy of tourism in the Third World', Annals of Tourism Research, vol. 9(2), pp. 331-358.

Butler, RW 1980, 'The Concept of a tourist area cycle of evolution: implication for management of resources', Canadian Geographer, vol. XXIV, no. 1, pp.5-12.

Butler, RW (ed.) 2006, 'The tourism area life cycle vol.1, 2', Aspects of Tourism, vol. 28, 29, Channel View Publications, Clevedon-Buffalo-Toronto.

Connell, J 1988, 'Sovereignty \& Survival. Island Microstates in the Third World', Research Monograph, no 3, Department of Geography, University of Sydney, Sydney.

David, G 2003, 'Mondialisation et recompositions territoriales et identitaires dans l'Océanie insulaire' in lles rêvées. Territoires et identités en crise dans le Pacifique insulaire eds D Guillaud. Ch Huetz de Lemps \& O Sevin, Presses de I'Université de Paris-Sorbonne, Paris, pp.141-178.

Dehoorne, O \& Saffache, P 2008, 'Le tourisme dans les îles et littoraux tropicaux : ressources et enjeux de développement', Études caribéennes [En ligne], vol. 9-10. DOI: 10.4000/etudescaribeennes.852. Available from: <http://journals.openedition.org/ etudescaribeennes/852>. [27 December 2018].

Flight Radar 24 2018, Nosy Be Fascene Airport. Available from: <https://www.flightradar24.com/data/airports/nos/arrivals>. [1 February 2018].
Freitag, TG 1994, 'Enclave tourism development. For whom the benefits roll?', Annals of Tourism Research, vol. 21, no. 3, pp. 538-554.

Gay, JCh 2001, 'L'ile-hôtel, symbole du tourisme maldivien', Les Cahiers d'Outre-Mer, vol. 213, pp. 26-52.

GoogleMaps, 2018. Available from: <https://www.google. pl/maps/@-13.3094475,48.2375171,25979m/ data $=$ !3m1!1e3>. [1 February 2018].

Gormsen, E 1982, 'Tourism as a development factor in tropical countries. A case study of Cancun, Mexico', Applied Geography and Development, vol. 32, pp.65-80.

Gormsen, E 1997, 'The impact of tourism on coastal areas', GeoJournal, vol. 42(1), pp. 39-54.

Guébourg, JL 1999, Petites îles et archipels de l'océan Indien, Karthala, Paris.

Haldrup, M \& Larsen, J 2010, Tourism, performance and the everyday: Consuming the Orient, Routledge, London.

Hoareau, JF (ed.) 2016, Spécialisation touristique et vulnérabilité. Réalités et enjeux pour le développement soutenable des petits territoires insulaires [Tourism specialization and vulnerability. Realities and challenges for the sustainable development of small island territories], L'Harmattan, Paris.

Jędrusik, M, 2004, 'Nature and tourism on tropical and subtropical islands', Miscellanea Geographica, vol. 11, no. 1, pp. 271-280. DOI:10.2478/mgrsd-2004-0030. Available from: <https://content.sciendo.com/view/journals/mgrsd/11/1/ article-p271.xml> [27 December 2018].

Jędrusik, M 2011a, 'Krajobraz kulturowy a turystyka na wyspach u północno-zachodniego wybrzeża Madagaskaru' [Cultural landscape and tourism on the islands off the NW coast of Madagascar] in Krajobraz kulturowy a turystyka [Cultural landscape and tourism] eds J Wojtanowicz \& L Zbucki, Wydawnictwo PSW JPII. Biała Podlaska, pp. 25-36.

Jędrusik, M 2011b, 'The role of islands located off the northwest coast of Madagascar in modern tourism development' in UGI 2011 Regional Geographic Conference "United and Integrated with the World" Conference Proceedings. Santiago de Chile (CD-disc).

Jędrusik, M 2011c, 'Island studies. Island geography. But what is an island?', Miscellanea Geographica, vol. 15, no. 1, pp. 201-212. DOI: $10.2478 / v 10288-012-0012-7$. Available from: <https://content.sciendo.com/view/journals/mgrsd/15/1/ article-p201.xml>. [27 December 2018].

Larsen, J \& Urry, J 2011, The Tourist Gaze 3.0. (3. ed.), SAGE Publications, Los Angeles.

Le petit futé de Madagascar, Edition 2006 2006, Nouvelles Editions de l'Université, Paris.

Liszewski, S 1995, 'Przestrzeń turystyczna' [Tourism space], Turyzm, vol. 5, no. 2, pp. 87-103.

Lonely Planet 2018, Nosy Be hotels. Available from: <https:// www.lonelyplanet.com/madagascar/nosy-be/hotels/a/ lod/355395>. [1 February 2018]. 
MISCELLANEA GEOGRAPHICA - REGIONAL STUDIES ON DEVELOPMENT

Vol. 23 • No. 1 • 2019 • pp. 23-32 • ISSN: 2084-6118 • DOI: 10.2478/mgrsd-2019-0001

Petit, M 2006, L'Homme \& la Foret à Madagascar. Quatre siècles d'évolution du paysage forestier, Université d'Antananarivo, Antananarivo.

Petit futé Madagascar 2014 2014, Nouvelles Editions de I'Université, Paris.

Madagasikara et ses 22 Régions 2006, IGHN, Antananarivo.

Miossec, JM 1977, 'Un modèle de l'espace touristique', L'Espace Géographique, vol. 6(1), pp. 41-48.

Oppermann, M 1993, 'Tourism space in developing countries', Annals of Tourism Research, vol. 20(3), pp. 535-556.

Pitcher, G \& Wright, PC 2004, Madagascar\&Comoros, Lonely Planet Publications, Victoria.

Podhorodecka, K 2017, 'Tourism economies and islands' resilience to the global financial crisis', Islands Studies Journal, Ahead of print. Available from: <https://doi. org/10.24043/isj.43>. [1 February 2018].

Podhorodecka, K 2018, 'Island tourism during the global economic crisis', Miscellanea Geographica, vol. 22, no. 3, pp. 130-141. Available from: <https://doi.org/10.2478/ mgrsd-2018-0022>. [20 October 2018].

Resort Guides 2018, Search Resorts at Nosy Be. Available from : <http://www.resortsguides.com/?fr=13888\&gclid= CjwKCAiA5OrTBRBIEiwAXXhT6Co9cY0flALEJirn1W5iL bf3-SWVqMVo8fK7FNFwhVbt-nr4IWM0_RoCqZUQAvD_ BwE)>. [1 February 2018].

'Révélations sur l'effroyable lynchage de NosyBe', Le Parisien Actualité 20 février 2015, 7h00. Available from : http:// www.leparisien.fr/espace-premium/actu/revelations-sur-leffroyable-lynchage-de-nosybe-20-02-2015-4547897.php [1 February 2018].

Robequain, Ch 1958, Madagascar et les bases dispersées de l'Union Française, Presses Universitaires de France, Paris.

Singaravelou, P 1989, 'Le rôle du tourisme dans l'économie mauricienne' in lles et tourisme en milieux tropical et subtropical, CEGET-CRET, Talence, pp. 265-278.

The World Bank Data International Tourism, Madagascar 2018. Available from: <https://data.worldbank.org/indicator/ ST.INT.ARVL?locations=MG>. [15 February 2018].

Travel Madagascar 2018, Madagascar Travel Guide. Available from: <http://www.travelmadagascar.org/CITIES/Nosy-Be. html>. [1 February 2018].

TripAdvisor New Zealand 2018, Nosy Be Antsiranana Province. Available from : <https://www.tripadvisor.co.nz/Hotelsg479206Nosy_Be_Antsiranana_Province-Hotels.html)>. [1 February 2018].

TripAdvisor New Zealand 2018, Nosy Iranja Lodge. Available from : <https://www.tripadvisor.co.nz/ShowUserReviewsg479207-d477464-r122939144-Nosy_Iranja_Lodge-Nosy_ Iranja_Antsiranana_Province.html\#>. [7 February 2018].

TripAdvisor New Zealand 2018, Nosy Iranja Lodge. Available from : <https://www.tripadvisor.co.nz/ShowUserReviewsg479207-d477464-r158511267-Nosy_Iranja_Lodge-Nosy_ Iranja_Antsiranana_Province.html\#>. [7 February 2018].

Vellas, F \& Cauet, JM 1997, Le tourisme et les îles. Sociétés et économies insulaires, L'Harmattan, France, Canada.

Wikipedia 2018, Air Madagascar. Available from: <https:// fr.wikipedia.org/wiki/Air_Madagascar>. [1 February 2018].

Wikipedia 2018, Nosy Be. Available from: <https://fr.wikipedia. org/wiki/Nosy_Be>. [1 February 2018].

Wilkinson, PF 1989, 'Tourism in the small island states of the Commonwealth Antilles' in lles et tourisme en milieux tropical et subtropical, CEGET-CRET, Talence, pp. 105-124.

World Tourism Organization 2016, Compendium of Tourism Statistics dataset [Electronic], UNWTO, Madrid. Available from: <http://statistics.unwto.org/news/2016-02-22/ methodological-notes-tourism-statistics-database-2016edition>. [1 February 2018]. 